\title{
A LA CARTE URBAN POLICIES. MEGA-EVENTS: FROM EXCEPTIONALITY TO CONSTRUCTION OF ORDINARY PLANNING PRACTICES. A LOOK AT ITALY: CASE STUDY OF THE 2006 WINTER OLYMPIC GAMES IN TURIN
}

\author{
Alexia De Steffani \\ IUAV (University Institute of Architecture, Venice), Venice, Italy \\ E-mail: alideste@tiscali.it
}

\begin{abstract}
Considering the increasing focus on mega-events studies, in parallel to the growing interest demonstrated by local administrators and European cities towards hallmark events, the article aims to analyse this new trend and existing relationship between the regular policies and rise of new forms of urban management. It deals with Italy as a case study: since the 1990s several Italian cities have been systematically participating in competitions for mega-events in order to initiate development projects. More precisely, the article focuses on Turin, which is the first Italian city to have embraced this strategy systematically. The analysis of this case-study allows us to highlight a rise of a profound change within trends of mega-events: mega events have started to lose their main features - such as ephemerality, exceptionality and occasionality - and have turned into something close to the ordinary urban practices.
\end{abstract}

Keywords: mega events, urban renewal, urban competition.

\section{Introduction}

The 1990 s can be picked as a turning point in the understanding of the European contemporary city.

After a period of crisis, during which cities were supposed to face a scaling-down process, nowadays they have gained the limelight of international debate.

Since the late 1970s, derelict European industrial cities have faced increasing structural changes: the growth in communication strategies, the rise of new media, economic restructuring - as a consequence of globalization processes - and such demise of large-scale industrial complexes have given rise to deep changes in the structure of contemporary cities.

Since the 1990s, European cities have confirmed themselves to be undisputable protagonists of contemporary times (Nuvolati 1999) and have gained new centrality in the debate in the field (Secchi 2006). Economic and cultural globalization has increased the competition among cities and has turned cities into consumer goods to be marketed as brands which need to be advertised.

According to this renewed scenario, many municipalities have chosen urban tourism as a key instrument through which they can ignite urban regeneration moving from Fordism to post-Fordism, from a production-based society to a cultural consumption-based society (Judd, Fainstein 1999).

In the wake of such new approaches, mega-events and other urban spectacles have become strategic tools in traditional urban policies so as to meet the new challenges posed by the interurban competition.
Bidding for mega-events means earning both, the mass media attention and conspicuous economic resources, which can be used to activate urban development.

Over the past ten years, Italy too tried to acquire new economic resources by hosting great events. Italian municipalities - mainly of mature industrial cities - have showed their skills in using mega-events as an engine for previously started projects. They have begun to draw up new urban policies starting from the ephemeral occasion offered by temporary events.

The main purpose of this study is to reconstruct Italian paths towards the strategy of mega-events, mainly from the 1990s up to the present.

Hence, this knowledge allows making comparisons with similar European trends and understanding the transformations that occurred in traditional urban tools and policies.

It also serves as an outline of the existing relationship between two opposing archetypes: the "ordinary" which is typical for traditional urban policies and urban plans - and the "exceptional" - which is the main feature of mega-events.

According to these advertences (de Magistris 2004), my starting hypothesis is that mega-events - such as expos, Olympic Games, other sport, political and cultural events - have turned from extraordinary occasions of urban development into ordinary management practices, which lead the construction of the contemporary city. 


\section{Mega-Events: \\ Theoretical Background}

In parallel to the increasing attention demonstrated by larger number of municipalities towards great events, literature in this field has sensibly increased.

Starting from the late 1980s, several books and researches have been published and mega events - as a topic - have trespassed the tight boundaries of specialist literature gaining common interest of urban administrators and entering into several urban agendas.

Firstly, some specific disciplines - such as economy, sociology and urban planning policy - began to get interested in this topic. They have started a now consolidated theoretical framework, in which mega events are seen as engines for urban modernization and regional development.

Anyway, this corpus of studies seems to have forgotten that hallmark events are all but new phenomena having their roots in the $19^{\text {th }}$ century fairs and expositions.

Moreover, this research tries to consolidate a narration, in which urban events are considered because of their exceptional and ephemeral character. It is important to highlight that contemporary mega-events have changed their nature turning themselves into something that is all but exceptional episode (de Magistris 2004). Even if they are brief events - with a well-planned beginning and one precise end - their legacy, material as well immaterial, has a very long period of life.

Since the 1990s, after the crisis of the Nation State and the new emerging role of cities, mega events seem to have turned themselves into something new that should be re-conceptualized. They have lost their older main characteristics and have turned from episodic and extraordinary events to recurrent and ordinary urban policies.

During this decade, judging by the changes occurring in the post-modern society, we have seen, on one hand, an increase in new typologies of urban events and, on the other, a certain recurrence of these events. In other words, they are no more episodic occasions of transformation.

In more recent years, other studies have been conducted within "Cultural Studies" and "Design Studies". This research is more interested in the design processes related to mega-events and it often focuses on a singular event.

Also "Urban Studies" as a discipline have suggested useful interpretation keys in order to theorize a possible taxonomy of all different events in the light of their economic, social, urban and architectural legacy.

According to the theoretical scenario, it is possible to say that, in a period of crisis of traditional urban paradigms, mega projects and spectacular events may embody the changing modes of urban growth and rise of new approaches to town planning, new urban policies and new urban actors (Olmo 2004).

Table 1. Field of research and possible periodization

\begin{tabular}{|l|l|l|l|}
\hline $\begin{array}{c}\text { Research } \\
\text { Field }\end{array}$ & $\begin{array}{c}\text { Period of } \\
\text { Interest }\end{array}$ & $\begin{array}{c}\text { Events } \\
\text { mainly } \\
\text { studied }\end{array}$ & \multicolumn{1}{c|}{$\begin{array}{c}\text { Field } \\
\text { of interest }\end{array}$} \\
\hline Economy & $\begin{array}{l}1980 \text { s-up } \\
\text { to now }\end{array}$ & $\begin{array}{l}\text { Olympic } \\
\text { Games and } \\
\text { other sport } \\
\text { events }\end{array}$ & $\begin{array}{l}\text { Economic } \\
\text { impact of ME }\end{array}$ \\
\hline $\begin{array}{l}\text { Urban } \\
\text { Policy }\end{array}$ & $\begin{array}{l}1990 \text { s-up } \\
\text { to now }\end{array}$ & $\begin{array}{l}\text { Olympic } \\
\text { Games / } \\
\text { Expos }\end{array}$ & $\begin{array}{l}\text { Relationship be- } \\
\text { tween ME and } \\
\text { urban policies } \\
\text { and instruments }\end{array}$ \\
\hline Sociology & $\begin{array}{l}1990 \text { s-up } \\
\text { to now }\end{array}$ & $\begin{array}{l}\text { Olympic } \\
\text { Games / } \\
\text { Expos / Sport } \\
\text { Events / } \\
\text { Political } \\
\text { Events }\end{array}$ & $\begin{array}{l}\text { Sociological } \\
\text { legacy / } \\
\text { Phenomena of } \\
\text { gentrification / } \\
\text { Impact on job } \\
\text { placement }\end{array}$ \\
\hline $\begin{array}{l}\text { Urban } \\
\text { Studies }\end{array}$ & $\begin{array}{l}1990 \text { s-up } \\
\text { to now }\end{array}$ & $\begin{array}{l}\text { Olympic } \\
\text { Games / } \\
\text { Expos }\end{array}$ & $\begin{array}{l}\text { Urban legacies / } \\
\text { Infrastructural } \\
\text { and morpholo- } \\
\text { gical transfor- } \\
\text { mation }\end{array}$ \\
\hline $\begin{array}{l}\text { Cultural } \\
\text { Studies }\end{array}$ & $\begin{array}{l}1990 \text { s-up } \\
\text { to now }\end{array}$ & $\begin{array}{l}\text { Olympic } \\
\text { Games / } \\
\text { Expos / } \\
\text { Capital of } \\
\text { Culture and } \\
\text { other festivals }\end{array}$ & $\begin{array}{l}\text { International } \\
\text { and World } \\
\text { Exhibitions } \\
\text { Monograph on a } \\
\text { singular event }\end{array}$ \\
$\begin{array}{l}1980 \text { s }- \\
\text { Origins of ME } \\
\text { to thein history } \\
\text { and evolution) }\end{array}$ \\
\hline
\end{tabular}

\section{The Italian Way of Mega-Events}

As explained in the paragraph above, the 1990s marked the rise of new trends in global economy and policy. This decade also saw the increase of new dynamics in urban growth and re-thinking process of urban tools and practices.

At the same time, international tourism shifted from the mass tourism, which was the other side of Fordism and industrial society, to new rhapsodic forms of travel - such as short-break holidays and urban tourism - which are the expression of post-modernism and contemporary society. With these new trends and proliferation of industrial decommissioning, urban regeneration and urban renewal emerged as a typical strategy of the 1990s marking the shift from a production-based economy to a consumptionand culture-based one. 
For this reason, facing the large-scale demise of industrial complexes, several municipalities started rethinking their ancient urban image and identity through bidding for mega events. Their common objective is the commodification of industrial complexes, the modernization and implementation of infrastructures in order to turn quite desolate cities into tourist destinations.

In other words, each city has to re-think its new image that can be advertised by appealing slogans in order to gain the limelight on the international stage.

According to this scenario, Italy may be chosen as a certain vantage point allowing observe such changes and providing several examples for comparison with similar European experiences.

Starting from the upheavals following the globalization and rise of new geopolitical scenarios - consequently the crisis of a Nation State as well as the streamlining processes of the European Union and introduction of Euro - Italian cities also began directing their urban policies towards the mega-event strategies.

Winning the competition for 2006 Winter Olympic Games in Turin and Milan's successful bidding for Expo 2015 has resulted not only in renewed debate in the field, but also in increasing interest by urban administrators who started looking at similar European experiences in order to emulate their strategies (e.g. Barcelona 1992).

Turin represents the best-known Italian example in application of the mega-events strategy.

It is not a solitary case, however, in the Italian scenario: another important instance is Genoa (Bisio, Bobbio 2004; Guala 2007) which, starting with the Columbus Celebrations in 1992 to Genoa European Capital of Culture in 2004, has demonstrated its skills for using mega-events as tools for transformation and modernization of its historical city centre and the area of its old industrial port, following a well-known European tradition of water-front regeneration (e.g. Bilbao, Barcelona, Valencia).

Like other European cities, Genoa has profited from two great events to renew its city centre and convert its industrial spaces - mostly being devoted to culture and leisure - seeking to reinvent its identity and attract increasing tourist flows. The city's administrators also decided to commission the project of the new port to an important Italian figure in architecture, Renzo Piano. This choice can be ascribed to the increasing global phenomenon of the "Archistar" system (Lo Ricco, Micheli 2003): Genoa tried to renew its city-brand merging in with an appealing mega-project by a famous architectural firm.

Like Genoa, other medium and small-sized cities such as Trento, Modena, Mantua and Ferrara - have em- braced this festival strategy in order to rebrand themselves competitively and attract conspicuous tourist flows.

As final instances, Rome and Naples are particularly productive case studies in observance of new trends in mega-event development.

Rome has confirmed its traditional calling for cultural tourism: new facilities, such as Ara Pacis Museum, the Park of Music and MAXXI Museum of the Arts of the $21^{\text {st }}$ Century have drawn the extensive attention of the mass-media.

Although it is not particularly innovative, this strategy follows the suit of the Centre Pompidou and Guggenheim in Bilbao (de Magistris 2004).

In recent years, mainly thanks to Mayor Gianni Alemanno, Rome seems to have embraced a mega-events strategy with the renewed impetus demonstrating a common trend, by which great events seem to be the most affordable urban government practice.

Following the $13^{\text {th }}$ Fina World Championship, the city has concentrated its all attempts to the "Millennium Project": Rome is working for its candidacy for the 2020 Olympic Games.

Naples has likewise started complex infrastructural projects - such as the underground line and Afragola highspeed station - and has transformed them into a media event.

Although such projects are not, point-blank speaking, mega-events, they present a similar strategy of promotion and similar objective. Through these construction works the city aims to promote urban requalification, diversify their economic system and encourage urban tourism.

Today Naples is preparing for its future candidacy to the Forum of Culture in 2013.

Summing this up, it is noteworthy that Italy has embraced such mega-events' strategy since the early 1990s starting with the Football World Cup in 1990. This event was looked upon as a strategic opportunity to modernize the whole nation. However, this event was a lost opportunity mainly because it was neither thought out nor planned on the basis of an organic and coherent strategy.

Following this lost opportunity Italy has started looking at other European experiences in order gain success in attracting new events to use them as an engine for urban development processes.

\section{Turin: from Shabby "Corporate Town" to "Capital" of the Ongoing Event}

Turin represents an important case, especially considering the city's age-old excellence in using mega-events as an engine for previously started policies and projects. 
Since it won the competition for the 2006 Winter Olympic Games, Turin has been showing a constant ability to capture mega-events and using them as a catalyst for regeneration of some demised industrial areas and consolidation of its mission for culture and tourism, which previously was overshadowed by its role as a capital of the automotive industry (Bagnasco 1986).

Starting with the Centenary Celebrations of Italian Unity in 1961 (Pace, Chiorino, Rosso 2006), a certain continuity may be seen in Turin's approach to urban spectacles and events.

The 1990s mostly saw the city gaining the limelight on the international stage thanks to a number of spectacular events, such as the nomination of the World Design Capital in 2008, the XXIII UIA World Congress of Architecture in 2009, the exhibition of the Turin Shroud in 2010, the MiTo International Music Festival since 2007 (from 1978 to 2006 it was known as September Music) and consolidation of the inner city museum system.

Such events have not only enhanced the city's calling for tourism and culture, but also transformed significantly its morphology and structure through development of new infrastructures, buildings and settings.

Table 2. Brief catalogue of Turin's great events from the $19^{\text {th }}$ to the mid $20^{\text {th }}$ century

\begin{tabular}{|l|l|l|l|}
\hline When & Event Typology & \multicolumn{1}{|c|}{ Where } & Urban Impact \\
\hline 1884 & $\begin{array}{l}\text { Italian General } \\
\text { Expo }\end{array}$ & $\begin{array}{l}\text { Parco } \\
\text { Valentino }\end{array}$ & $\begin{array}{l}\text { Small-scale, } \\
\text { poorly organi- } \\
\text { zed event } \\
\text { Legacy: } \\
\text { Medieval } \\
\text { Borough }\end{array}$ \\
\hline 1898 & $\begin{array}{l}\text { Italian General } \\
\text { Expo }\end{array}$ & $\begin{array}{l}\text { Parco } \\
\text { Valentino }\end{array}$ & $\begin{array}{l}\text { Small-scale, } \\
\text { poorly organi- } \\
\text { zed event }\end{array}$ \\
\hline 1902 & $\begin{array}{l}\text { International } \\
\text { Expo of Modern } \\
\text { Fine Arts }\end{array}$ & $\begin{array}{l}\text { Parco } \\
\text { Valentino }\end{array}$ & $\begin{array}{l}\text { Small-scale, } \\
\text { poorly organi- } \\
\text { zed event }\end{array}$ \\
\hline 1911 & $\begin{array}{l}\text { International } \\
\text { Expo of Industry } \\
\text { (Celebrations for } \\
\text { Italian Unity) }\end{array}$ & $\begin{array}{l}\text { Parco } \\
\text { Valentino }\end{array}$ & $\begin{array}{l}\text { Small-scale, } \\
\text { poorly organi- } \\
\text { zed event }\end{array}$ \\
\hline 1928 & $\begin{array}{l}\text { Italian National } \\
\text { Expo }\end{array}$ & $\begin{array}{l}\text { Parco } \\
\text { Valentino }\end{array}$ & $\begin{array}{l}\text { Small-scale, } \\
\text { poorly organi- } \\
\text { zed event }\end{array}$ \\
\hline 1961 & $\begin{array}{l}\text { Celebrations for } \\
\text { the Centenary of } \\
\text { the Italian Unity }\end{array}$ & $\begin{array}{l}\text { Southern } \\
\text { area of the } \\
\text { city in a } \\
\text { regenerated } \\
\text { area nearby } \\
\text { the river Po }\end{array}$ & $\begin{array}{l}\text { Large-scale } \\
\text { urban develo- } \\
\text { pment: cons- } \\
\text { truction of a } \\
\text { new quartier. } \\
\text { Legacy: } \\
\text { Palazzo Vela- } \\
\text { Palazzo del } \\
\text { Lavoro }\end{array}$ \\
\hline
\end{tabular}

Thanks to these events, Turin has also changed its role in its metropolitan region: mainly due to the 2006 Winter Olympics, the city has consolidated strategic infrastructural networks in the north-west area of Italy -known as the Milan-Turin-Genoa triangle - and has confirmed its tendency to grow as a part of the polycentric territory.

Since the first industrial decommissioning processes in late 1970s, Turin has tried both to move from a production-based to a consumption-based economy and develop a renewed brand image far from its industrial notoriousness as "automotive capital".

In such a way, the Winter Games worked as a catalyst for policies already started and aimed to evade from Turin's single-culture destiny.

\section{Turin 2006: Ongoing Process}

The 2006 Winter Olympic Games has mainly accelerated processes already started and acted as a catalyst for continuation of previous policies and urban projects.

The Games have also stressed out the strategic importance of the historical urban elite: above all the Fiat group and the Agnelli family played a strategic role both in winning the competition for the Games, the management process and in selection of areas on which the Games facilities were to be placed.

It is important to underline that the rethinking process of Turin is a long-term one, having its roots in the late 1970s and the class fights of the 1980s (see the well-studied "March of the 40,000").

The first step towards this transformation was the architectural competition for decommissioning Lingotto the historical factory of FIAT - in 1982. When Fiat decided to move its production from the Lingotto building, it was immediately clear that the historical factory would have not been destroyed. The international competition aimed to find out a new purpose - mainly related to culture and leisure - both for the building and its area.

One of the most evident outcomes of the 2006 Games was the reaffirmation of Lingotto's importance in the whole metropolitan region.

For this reason the 1980 s can be considered a turning point in the recent history of Turin: during this decade, the city began to rethink its role and rebrand its image through diversification of its economic and productive system.

Moreover, it has to be mentioned that the city decided to commission its new Town Plan exactly in the same period, when academics and town-planners had begun to question traditional urban instruments. 
The 1995 Town Plan had already given a blueprint for a wide urban project trying to revitalize and transform the decommissioned industrial areas.

The main objective of this Plan was the commodification and conversion of industrial legacies and services through a renewal of some abandoned areas. It is possible to say that this Plan aimed to weave the heterogeneous social and urban fabric within a coherent project (Bagnasco 1990).

It is in the light of the abovementioned scenario that the core project sustaining this Plan must be read. Gregotti, Cagnardi and Cerri drew a new strong urban centrality named Spina Centrale (Backbone) - which is a sort of mega-boulevard, which reminds of the $19^{\text {th }}$ Century urban tradition, running from the North southwards cutting the city into two halves.

Along this axis, the architects outlined four grey areas which were strategic transformation pieces of a more complex puzzle.

The 2006 Winter Olympics have worked as a catalyst of all these processes and have partially confirmed the morphological and setting choices of the 1995 Town Plan.

Most of the Olympic facilities and infrastructures have been located in the southern part of the city offering a chance to renew not only the industrial areas, but also the abandoned buildings - nearby the Lingotto area - built in 1961 for the Centenary Celebration of the Italian Unity.

Although Turin approved its new Town Plan in 1995 (its study had begun in 1986), it is important to remember that this decade faced a serious crisis in urban discipline.

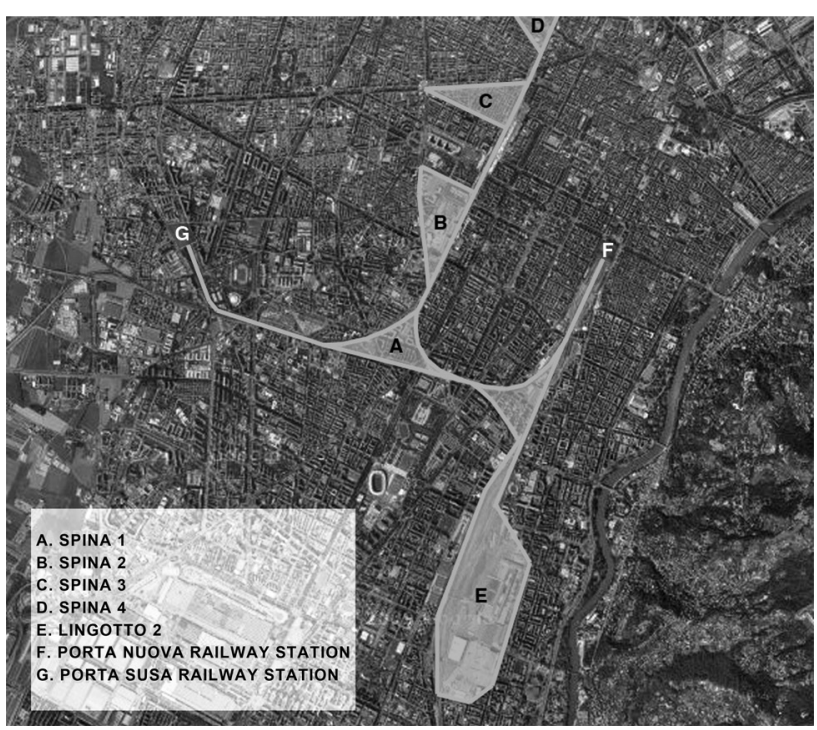

Fig. 1. 1995 Turin Town Plan: it outlines the expected transformation areas and new urban axes and centres
During these years Turin, like many other Italian cities, faced the reconsideration process of traditional urban instruments and policies. The effectiveness of the town plan was challenged and urban administrators and town planners tried to find innovative urban instruments. Among these, the Complex Programs seemed to offer possible solutions. The urban redevelopment programs were mainly launched in order to face the changing conditions in urbanism.

The 1990s in Italy not only meant industrial decommissioning processes, but also economic crisis, poor public resources for urban development, rise of a new demand for real estate and search for more effective town planning. To this end, town planners tried to solve the new urban issues (Secchi 2009) through new planning tools and policies capable of integrating different actors - such as the private and public ones - and managing the newly raised urban complexity.

In other words the 1990s (this process began in the early 1980s) saw the end of organic planning and rise of a new urban culture, which preferred the logic of integrated singular urban projects to the traditional comprehensive town plan.

Within this scenario, the 2006 Olympic Games seemed to offer a plausible answer: they had to act as a catalyst of ongoing already processes and allow for the development of precise fabrics in the city within a tight time-scale.

Moreover, they had not only a wide mediatic impact on the city, but also an economic one.

In parallel to the won competition for the Games, Turin also worked on its Strategic Plan (2000), which could be considered the key instrument for the city's future transformation.

Such a plan aims to create new synergies among public administrators, private entrepreneurs, local elites and citizens following an entrepreneurial approach to the city planning.

It also aims to outline some strategic vision for the future of the city: among these, "Tourism, Sport and Cultural Heritage" has been chosen as a strategic tool in order to reposition Turin on a global competitive stage.

Once again, the Games represented the way to enhance all these projects.

Finally, the award for organization of the Games also resulted in new research and debate in the field - which can be described as an important immaterial legacy: as an instance, in 2001 "Torino Incontra" and the Department of Humanities at Turin Politechnic (headed by Carlo Olmo) launched a study titled "How can a city win or lose the 
Table 3. Strategy of mega-events: Italian trends from the 1990s up to the present. This table outlines the rise of new Italian geographies of competitiveness and shows how mega-events have turned into ordinary urban policies in order to reach increasingly common objectives

\begin{tabular}{|c|c|c|c|}
\hline When & Where & Mega-event & Objective \\
\hline 1992 & Genoa & Columbus Celebrations & $\begin{array}{l}\text { Urban Renewal: water-front regeneration } \\
\text { (port area) }\end{array}$ \\
\hline 2004 & Genoa & European Capital of Culture & $\begin{array}{l}\text { Re-defining the cultural identity - Urban Renewal } \\
\text { (historical city centre) - enhancing a tourism-based } \\
\text { economy }\end{array}$ \\
\hline 2006 & $\begin{array}{l}\text { Turin and its surroun- } \\
\text { ding valleys }\end{array}$ & Winter Olympic Games & $\begin{array}{l}\text { Urban regeneration - infrastructural development - } \\
\text { enhancing urban competitiveness - } \\
\text { reconsidering urban identity }\end{array}$ \\
\hline 2008 & Turin & World Design Capital & $\begin{array}{l}\text { Enhancing urban tourism - branding new urban } \\
\text { Image }\end{array}$ \\
\hline 2009 & Turin & $\begin{array}{l}\text { UIA XXIII World Congress of } \\
\text { Architecture }\end{array}$ & $\begin{array}{l}\text { Enhancing urban tourism - branding new urban } \\
\text { image }\end{array}$ \\
\hline 2009 & Rome & XIII Fina World Championship & $\begin{array}{l}\text { Sporting infrastructure development - gaining the } \\
\text { media attention }\end{array}$ \\
\hline 2011 & Turin, Florence, Rome & $\begin{array}{l}\text { The } 150^{\text {th }} \text { Celebration of the Italian } \\
\text { Unity }\end{array}$ & $\begin{array}{l}\text { Enhancing urban tourism - branding new urban } \\
\text { image - modernization processes }\end{array}$ \\
\hline 2013 & Rome & GP F1 & Urban development (EUR area) \\
\hline 2015 & Milan & Expo & $\begin{array}{l}\text { Urban regeneration - enhancing urban tourism - } \\
\text { infrastructural development }\end{array}$ \\
\hline 2013 & Naples & Candidacy to the Forum of Culture & Urban regeneration: the area of Bagnoli \\
\hline 2019 & $\begin{array}{l}\text { Bari, Matera, Rimini, } \\
\text { Ravenna, Venice }\end{array}$ & $\begin{array}{l}\text { Candidacy to the European Capital } \\
\text { of Culture }\end{array}$ & $\begin{array}{l}\text { Re-defining the cultural identity - urban renewal- } \\
\text { enhancing tourism }\end{array}$ \\
\hline 2020 & Rome & $\begin{array}{l}\text { Candidacy to the Summer Olympic } \\
\text { Games }\end{array}$ & $\begin{array}{l}\text { Urban regeneration - infrastructural development - } \\
\text { enhancing urban competitiveness }\end{array}$ \\
\hline
\end{tabular}

Olympic Games?" This research shows how the city has begun to treat great events as strategic tools for urban development and modernization.

It is possible to affirm that what the Games have left behind cannot be limited to architecture and urban morphology only, but has also endowed the city with a wealth of urban policies, renewed know-how and cultural heritage

\section{Conclusions}

Events like the 2006 Turin Winter Games allow reflecting on the existing interaction among different time frames in urban planning and development: a great event having an ephemeral and brief nature with a clear "before" and "after", the success of the whole depends on the overlapping of several time frames: the long period of urban planning and development and the shorter period of the event itself.

It may be surprising how an event and rules of its management can interact with the ordinary and policies which are already in place.

Looking at Turin, the Winter Olympics represented the end of a long period of urban policies, which went back to the 1980s; they served as an economic and temporal catalyst for previous projects such as the metropolitan transit line, urban renewal processes, high-speed Turin-Milan railway line and inner-city museum system (de Rossi, Durbiano; Chiorino, Pace).

In 2009 OCSE Leed commissioned a study to Greg Clark in order to understand the strategic role of great events in urban policies and explore the opportunity of turning them into effective tools of management.

It is significant that Paolo Verri - director of the Turin Book Fair, Strategic Plan of the City and Committee for the Centenary of the Italian Unity - was chosen as editor for the Italian edition of this study. He has pointed out the opportunity to draw an "Italian Agenda" - from 2011 to 2021 - in order to plan future mega-events strategies. According to him, mega-events are a profitable opportunity to enhance not only tourism, but also urban development and they can also be turned into the possibilities of management. According to his vision, since 2011, Italy can really embrace a systematic approach to mega-events in order to reinforce the newly created metropolitan spine, which has been strengthened by the new high-speed railway, Turin-Milan - Bologna-Florence-Rome-Naples. 
This research confirms the starting hypothesis according to which mega-events seem to have replaced traditional urban practices. They have turned into a more common practice resorted by the cities in solving, or, probably, hidding, the crisis of their political and economic system.

Instead of facing the contemporary urban crisis through durable urban policies, the widespread trend is to recur to ephemeral solutions such as mega-events.

Several Italian municipalities are trying to transform extraordinary events into ongoing events in order to draw funds and become leaders in the urban competition.

From the point of view of urbanism, this means that urban administrators prefer to embrace the logic of punctual and short-term projects instead of drawing an organic and coherent urban plan.

\section{References}

Bureca, A.; Palandri, G. 1984. Venti progetti per il Lingotto. Milano: Etas.

Aimone, L.; Olmo, C. 1990. Le esposizioni universali 1851-1900. Il progresso in scena. Torino: Allemandi.

Amin, A.; Thrift, N. 2005. Città. Ripensare la dimensione urbana (En. Ed. Cities. Reimagining the Urban). Bologna: Il Mulino.

Bagnasco, A. (Ed.). 1990. La città dopo Ford. Il caso di Torino. Torino: Bollati Boringhieri.

Bagnasco, A. 1986. Torino. Un profile sociologico. Torino: Einaudi.

Bianchetti, C. 2008. Urbanistica e sfera pubblica. Roma: Donzelli.

Bobbio, L.; Dente, B.; Fareri, P.; Morisi, M. 1990. Metropoli per progetti. Attori e processi di trasformazione urbana a Firenze, Torino, Milano. Bologna: Il Mulino.

Bobbio, L.; Guala, C. 2002. Olimpiadi e grandi eventi. Verso Torino 2006. Roma: Carocci.

De Magistris, A. 1999. L'urbanistica della grande trasformazione 1945-1980, in Tranfaglia, N. (Ed.). Storia di Torino. Gli anni della Repubblica, Torino: Einaudi.

De Magistris, A. 2004. Ires Scenari 2008/12. Il ruolo dei grandi eventi nllo sviluppo urbano e regionale. Una lettura storica. Torino: Ires.

De Rossi, A., Durbiano, G. 2006. Torino 1980-2011. La trasformazione e le sue immagini. Torino: Allemandi.

Falco, L. 1984. Lingotto un problema di ristrutturazione urbana, Casabella: 486.

Getz, D. 1997. Events Management and Event Tourism. New York: Elmsford.

Hall, M. 1992. Hallmark Tourist Events: Impacts, Management and Planning. London: Bellhaven.

Judd, D. R.; Fainstein, S. S. (Ed.). 1999. The Tourist City. Haven and London: Yale University Press.

Lo Ricco, G.; Micheli, S. 2003. Lo spettacolo dell'architettura. Profile dell'archistar. Milano: Bruno Mondadori.

Nuvolati, G. 1999. La geografia dello sviluppo urbano in Europa. Origini storiche e scenari future, in Martinotti, G. (Ed.). La dimensione metropolitan. Bologna: Il Mulino.
Olmo, C. 2003. I dilemmi della rigenerazione, +Città: città delle immagini, città in rete: Urban Regeneration. Firenze: Alinea.

Pace, S.; Chiorino, C.; Rosso, M. 2005. Italia '61. Identità e miti nelle celbrazioni per il Centenario dell'Unità d'Italia. Torino: Allemandi.

Roche, M. 2000. Events and Modernity. London: Routledge.

Roche, M. 2000. Mega-events and Modernity: Olympics and Expos in the Growth of Global Culture. London: Routledge.

Secchi, B. A New Urban Question, in The Swiss Spatial Sciences Framework (S3F), November 19, 2009, Zurich.

Secchi, B. 2006. La città del Ventesimo secolo. Roma-Bari: Laterza.

Secchi, B. 1984. Le Condizioni sono Cambiate, Casabella: 498-499.

\section{A LA CARTE MIESTO POLITIKA. GRANDIOZINIAI IVYKIAI: NUO IŠSKIRTINUMO IKI EILINIO PLANAVIMO STATYBŲ PRAKTIKOS. ITALIJA: 2006 METŲ OLIMPINIŲ ŽAIDYNIŲ TURINE ATVEJIS}

\section{A. De Steffani}

Santrauka

Straipsnyje analizuojama nauja Europos miestų tendencija rengti j̇vairius grandiozinius renginius. Nagrinejjamas Italijos atvejis, kai keletas miestų atkakliai siekia organizuoti milžiniškus renginius, tokius kaip olimpinès žaidynès. Turino miestas šios progos siekẻ sistemingai. Analizuojama, kaip kito išskirtinių renginių mada, kaip tokie dideli ivvykiai prarado savo pagrindinius bruožus efemeriškumą, išskirtinumą ir individualumą, ir tapo miestų planavimo kasdienybe.

Reikšminiai žodžiai: grandioziniai ịvykiai, miesto atnaujinimas, urbanistinis konkursas. 